\title{
Root-Knot Nematode (Meloidogyne incognita) on Bitter Melon (Momordica charantia) near Darwin, Australia
}

\author{
S. K. Singh $\cdot$ B. Conde $\cdot$ M. Hodda
}

Received: 19 March 2012 / Accepted: 5 April 2012 /Published online: 27 April 2012

(C) Australasian Plant Pathology Society Inc. 2012

\begin{abstract}
The Root-Knot nematode Meloidogyne incognita was identified morphologically from diseased Bitter Melon root samples taken from a farm at Buckley Road, Humpty Doo, Darwin. Meloidogyne species have been recorded from the Northern Territory on various hosts including bitter melon, but none were identified to species, so this is the first report confirming Meloidogyne incognita on Bitter Melon from the Northern Territory, Australia.
\end{abstract}

Keywords Root-knot nematode diagnosis · Perineal pattern · Bitter Melon pests · Asian vegetables

Bitter Melon (Momordica charantia), also commonly referred to as Bitter Gourd, Balsam Pear, Bitter Cucumber, and African Cucumber is a vegetable consumed in most Asian countries with many culinary and herbal medicine uses (Basch et al. 2003; Behera et al. 2010). In Australia, Bitter Melon is grown mainly in the Northern Territory, Queensland and New South Wales and in smaller quantities in other states to meet local market demand (Morgan and Midmore 2002). Bitter Melon production in the Northern Territory has steadily increased as a result of increased plantings by new Asian growers (Smith

S. K. Singh $\cdot$ M. Hodda

CSIRO Ecosystem Sciences,

GPO Box 1700, Canberra, ACT 2601, Australia

B. Conde

Department of Resources, Northern Territory Government, GPO Box 3000, Darwin, NT 0801, Australia

\section{S. K. Singh $(\bowtie)$}

Cooperative Research Centre for National Plant Biosecurity, Bruce, ACT 2617, Australia

e-mail: sunil.singh@csiro.au
2001) and is an important crop in the Asian vegetable industry (Midmore et al. 2004).

In September 2011, diseased Bitter Melon plants showing above-ground symptoms of wilting and dying (Fig. 1) were observed on a farm at Buckley Road, Humpty Doo, Darwin. These symptoms could have been due to several root pathogens, of which nematodes were only one. The root systems of the plants were examined and found to be heavily infected with root-knot nematodes $(100 \%$ of root system) forming large coalescing root galls (Fig. 2). The infected root samples were sent to CSIRO Ecosystem Sciences in Canberra, for root-knot nematode species diagnosis.

Female nematodes were dissected from the infected roots and processed for morphological examination as outlined in Shurtleff and Averre (2000). Male and juvenile specimens were obtained from the infected roots by cutting the roots into small pieces and incubating them at room temperature $\left(22^{\circ} \mathrm{C}\right)$ for $48 \mathrm{~h}$ in a Petri dish half filled with distilled water. Identifications were confirmed on specimens fixed in formaldehyde for 2 weeks, then processed to glycerol by the slow method and mounted on permanent slides (Hooper 1986). The slides are deposited in the Australian National Nematode Collection held within the ANIC at CSIRO in Canberra. The morphological features of the female, male and juvenile specimens (presented below) matched the most recent description for Meloidogyne incognita provided in Hunt and Handoo (2009). Measurements: mean \pm standard error $(\mu \mathrm{m})$ Female $(N=10)$ length $=570 \pm 65$, diameter $=340 \pm 50$, stylet length $=$ $15 \pm 0.5$, stylet basal knobs rounded and offset and body pear shaped without any posterior protuberance. Typical perineal pattern oval shape, high squared dorsal arch, striae wavy lateral field absent (Fig. 3). Male $(N=1)$ length $=1375$, stylet length $=24$, spicule $=29$, gubernaculum 
Fig. 1 Wilting and drying out of Bitter Melon caused by Meloidogyne incognita. Other pathogens or environmental stress may cause similar symptoms either alone or in combination with nematodes, however nematodes are often overlooked in searching for the cause of these symptoms

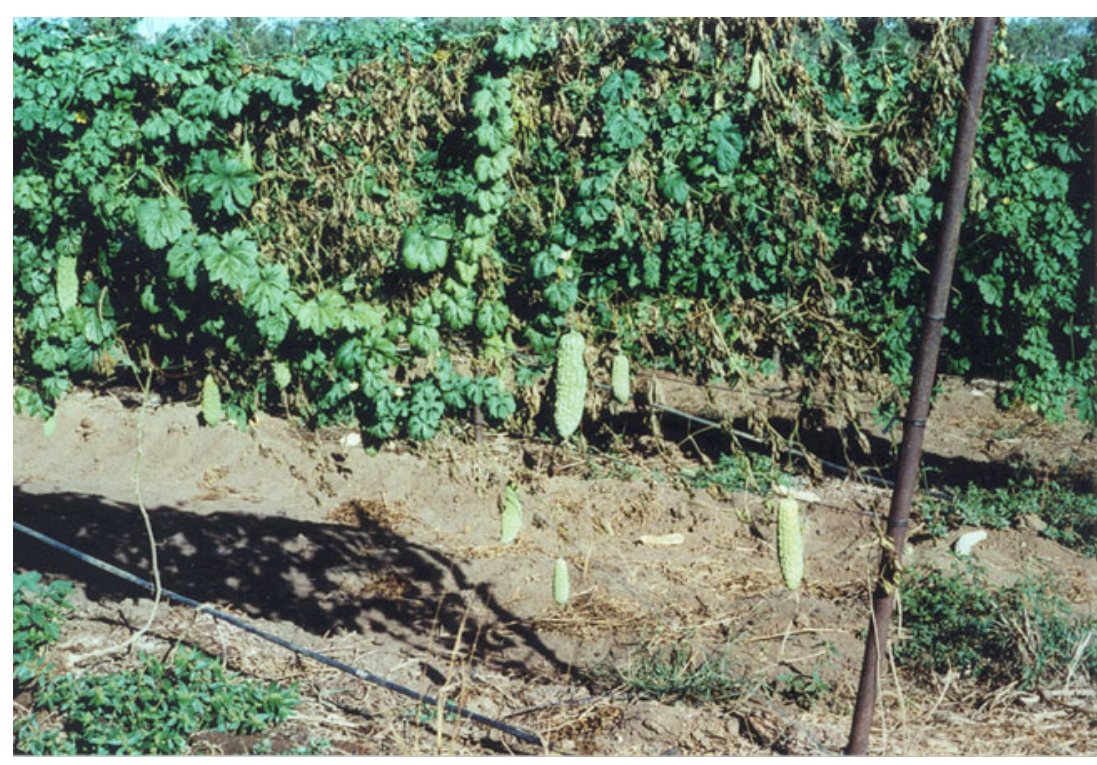

Fig. 2 Bitter Melon root system showing heavy root galling, characteristic of Root-Knot Nematodes. Although characteristic of the genus Meloidogyne, diagnosis to species requires examination of the nematodes

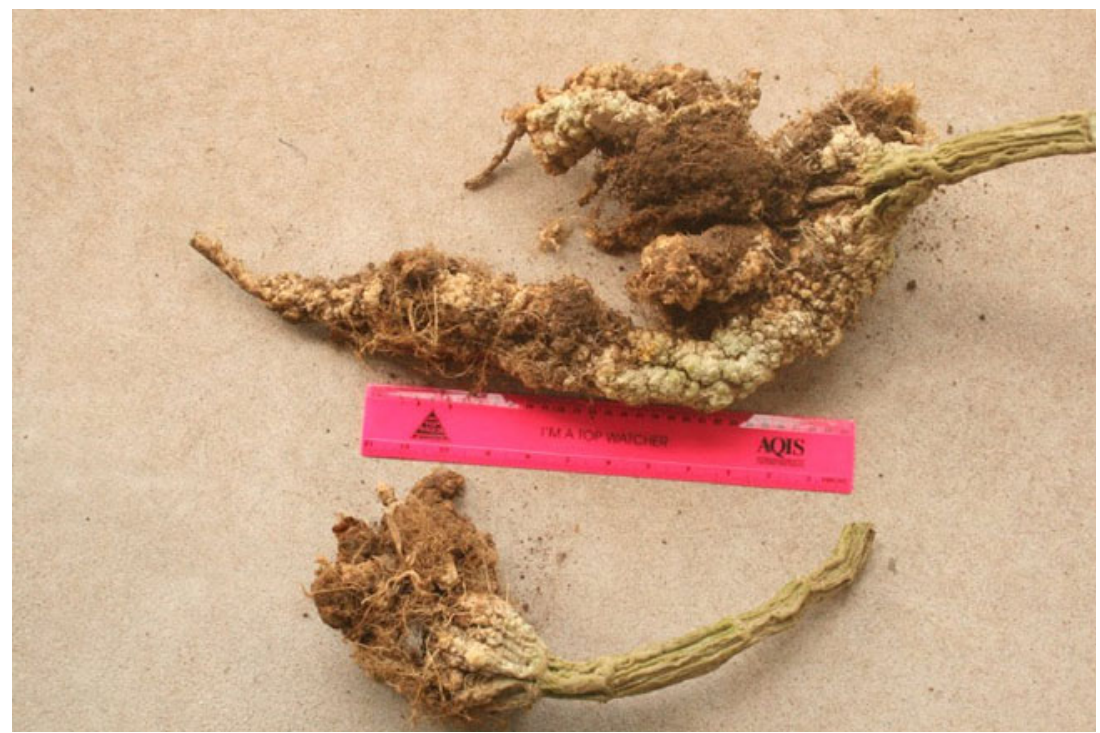

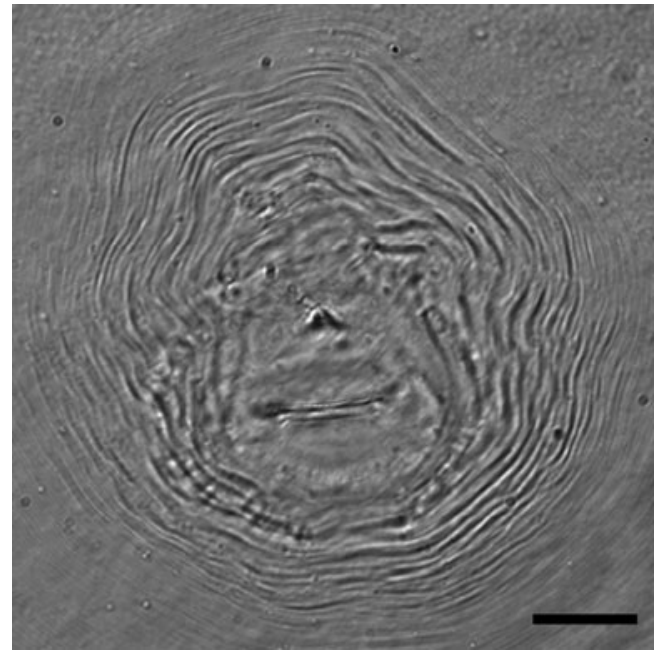

Fig. 3 Typical $M$. incognita perineal pattern showing high squared dorsal arch, wavy striae and lateral field absent. Scale bar $=22 \mu \mathrm{m}$ length $=12$, labial region not offset, labial disc elevated, basal knobs offset, rounded. Juvenile $(N=5)$ length $=365 \pm 30$, stylet length $=11 \pm 0.5$, tail length $=49 \pm 5$, hyaline tail length $=$ $9.8 \pm 0.4$, hemizonid anterior to excretory pore, tail tip rounded.

In addition to $M$. incognita, eight other Meloidogyne species have been recorded in Australia and can be distinguished from each other based on a combination of morphological characteristics (Table 1). M. javanica, the other common rootknot species in the Northern Territory, can be distinguished easily from $M$. incognita on the basis of female perineal pattern.

M. incognita is highly pathogenic on Bitter Melon elsewhere (Anwar and McKenry 2010; Chandra et al. 2010; Chen and Tsay 2006). Hence it could become a damaging pest of Bitter Melon in the Northern Territory. The use of green manure (Sudax sorghum) in the Northern Territory and soil amendments (saw dust and chicken manure) by 


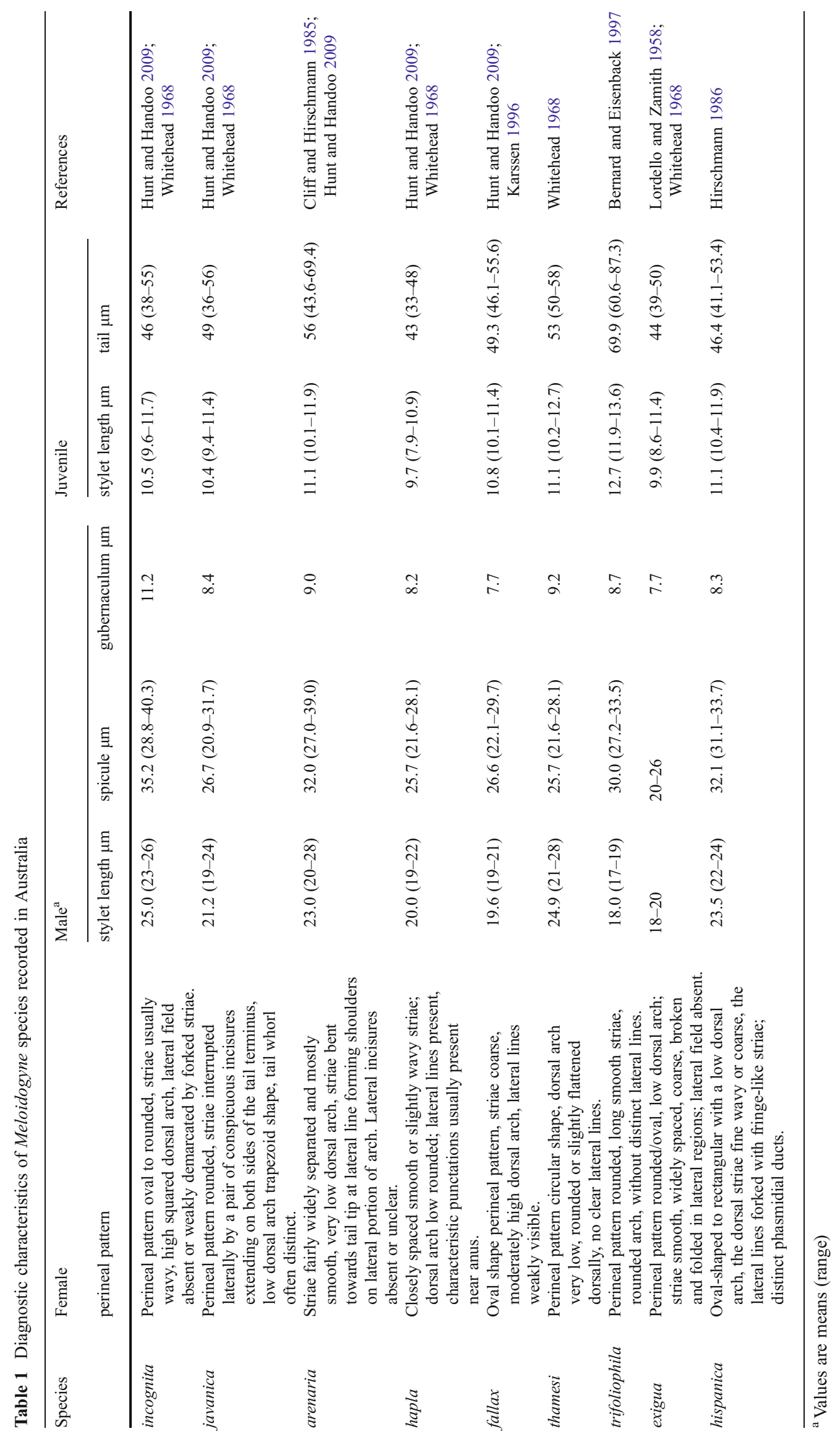


Queensland ginger growers to manage root knot nematodes has had some success and could be investigated further as a management option (Conde et al. 1999). Further studies on root-knot nematodes in the Northern Territory will be necessary to determine whether there are other species of nematodes causing damage to Bitter Melon, to assess crop losses and to develop better management strategies.

The authors thank Mr. Stuart Smith and Mr. Mark Traynor (Department of Resources, Northern Territory Government) for collection of root samples and Ms. Lois Ulyatt (Department of Resources, Northern Territory Government) for preparation and dispatch of samples from Darwin. The authors acknowledge the support of the Australian Government's Cooperative Research Centres Program.

\section{References}

Anwar SA, McKenry MV (2010) Incidence and reproduction of Meloidogyne incognita on vegetable crop genotypes. Pak J Zool 42:135-141

Basch E, Gabardi S, Ulbricht C (2003) Bitter Melon (Momordica charantia): a review of efficacy and safety. Am J Health Syst Pharm 60:356-359

Behera TK, Behera S, Bharathi LK, John KJ, Simon PW, Staub JE (2010) Bitter Gourd: Botany, horticulture, breeding. Horticultural Rev 37:101-141

Bernard EC, Eisenback JD (1997) Meloidogyne trifoliophila n. sp. (Nemata: Meloidogynidae) a parasite of clover from Tennessee. J Nematol 29:43-54

Chandra P, Sao R, Gautam SK, Poddar AN (2010) Initial population density and its effect on the pathogenic potential and population growth of the root-knot nematode Meloidogyne incognita in four species of cucurbits. Asian J Plant Pathol 4:1-15
Chen P, Tsay TT (2006) Effect of crop rotation on Meloidogyne spp. and Pratylenchus spp. populations in strawberry fields in Taiwan. J Nematol 38:339-344

Cliff GM, Hirschmann H (1985) Evaluation of morphological variability in Meloidogyne arenaria. J Nematol 17:445-459

Conde B, Pitkethley R, Connelly M, Ulyatt L (1999) Root knot nematode, a serious problem of vegetables in the top end of the Northern Territory. Australasian Nematology Newsletter 10:19-20

Hirschmann H (1986) Meloidogyne hispanica n.sp (Nematoda, Meloidogynidae), the Seville root-knot nematode. J Nematol 18:520-532

Hooper DJ (1986) Handling, fixing, staining and mounting nematodes. In: Southey JF (ed) Laboratory methods for work with plant and soil nematodes. Her Majesty's Stationery Office, London, pp 59-80

Hunt DJ, Handoo ZA (2009) Taxonomy, identification and principal species. In: Perry RN, Moens M, Starr JL (eds) Root-knot Nematodes. CABI, Wallingford, pp 55-97

Karssen G (1996) Description of Meloidogyne fallax n.sp (Nematoda: Heteroderidae), a root-knot nematode from the Netherlands. Fund Appl Nematol 19:593-599

Lordello LGE, Zamith APL (1958) On the morphology of the coffee root-knot nematode, Meloidogyne exigua Goeldi, 1887. Proc Helm Soc Wash 25:133-137

Midmore D, Gallacher D, Morgan W, Nguyen V, Hay F, McLaughlin P, Thomson G, Blackburn K, Gosbee M, McVeigh V, Wearing A, Loader L, Hastings J, O'Hare T (2004) Consolidating the Asian vegetable industry building on past achievements and actions for the future. RIRDC Publication No. 04/028 Rural Industries Research and Development Corporation. Canberra Australia

Morgan W, Midmore D (2002) Bitter Melon in Australia. RIRDC Publication No. 02/134 Rural Industries Research and Development Corporation. Canberra, Australia

Shurtleff MC, Averre CW III (2000) Diagnosing plant diseases caused by nematodes. American Phytopathological Society Press, Minnesota

Smith ESC (2001) Review of horticultural and agricultural developments in the NT from 1991-1998. In: Young G (ed) Proceedings of the sixth workshop for tropical agricultural entomologists Darwin, May 1998. Technical Bulletin no 288, pp 5-10

Whitehead AG (1968) Taxonomy of Meloidogyne (Nematoda: Heteroderidae) with descriptions of four new species. Trans Zool Soc Lond 31:263-401 